\title{
THE CAUSAL LINK BETWEEN SAVINGS AND ECONOMIC GROWTH IN BOSNIA AND HERZEGOVINA
}

Irma Đidelija

\section{Abstract}

The causal link between savings and economic growth has been extensively discussed in the economic growth and development literature, but the question of the direction of this link has not yet been clearly defined. The aim of this paper is to determine the direction and intensity of savings causality (components of private savings) and economic growth in Bosnia and Herzegovina. Granger's causality test, the TodaYamamoto procedure, was applied to test for causality between savings and economic growth. The results of Granger's causality test indicated that there is no causal link between components of private savings with economic growth in Bosnia and Herzegovina. It was found that among the variables there is cointegration, but not causality, which means that the variables have a common stochastic trend. This fully corresponds to the characteristics of the Bosnia and Herzegovina's economy.

Keywords: Saving, economic growth, macroeconomics, econometric analysis

JEL Classification: C32, E21

\section{Introduction}

One of the most important issues in any economy, regardless of the degree of its growth and development, is to ensure sufficient and quality funds to finance the economic growth. Given that foreign capital is quite expensive and risky to finance domestic investment and economic growth, domestic capital is considered a much more favorable and secure source of funds. Savings are most often mentioned in the literature as a domestic source of funds. The relationship between savings and economic growth is defined in the economic literature through the three most important theories of economic growth, which are: Keynesian theory of growth, Harrod-Domar's theory and Solow's theory.

The relationship between savings and economic growth, given its economic significance, has been the subject of numerous empirical studies. These works did not give unambiguous results in terms of the direction and intensity of the causality of savings and economic growth, neither in the short nor in the long run.

Therefore, this paper aims to examine the problem of endogenous savings and economic growth in the small, underdeveloped economy of Bosnia and Herzegovina. In this case, the focus is on private
Irma Đidelija, PhD
Assistant Professor
Faculty of Economics
University „Džemal Bijedić“ in Mostar
E-mail: irma.djidelija@unmo.ba
Address: Vrapčići bb, 88000 Mostar,
Bosnia and Herzegovina
ORCID: 0000-0003-1666-7363 
savings, looking at its individual components separately: household savings and savings of private for-profit companies. The reason for this is the fact that private savings, and especially its component of household savings, is recording continuous growth in Bosnia and Herzegovina, despite the great financial crisis in 2008. Also, private savings, according to the Central Bank of Bosnia and Herzegovina (quarterly bulletins from 2000-2016), is the dominant part of national savings, which is another reason to include only private savings in the model of this survey.

Private savings in Bosnia and Herzegovina are mostly realized in the form of deposits given the dominance of the banking sector in the financial markets. Thus, private savings in Bosnia and Herzegovina, viewed as the sum of long-term deposits, are growing despite the recent global financial crisis, but also the slowdown in economic growth and political instability in the country. It can be seen from the bulletin of the Central Bank of Bosnia and Herzegovina that at the end of September 2016 (in this analysis, eight years before and eight years since the beginning of the crisis were observed), total household deposits amounted to BAM 10.25 billion. This is also the largest growth in deposits so far. The share of household deposits in total deposits of commercial banks in Bosnia and Herzegovina is $59.6 \%$. Compared to the end of September of the previous year, 2015, household deposits increased by $6.6 \%$ or BAM 633.5 million. Compared to December 2008, when the economic crisis began, deposits are constantly growing in the range of $8-15 \%$ annually. Thus, a cumulative growth of deposits of $97 \%$ or BAM 5.05 billion was achieved.

Based on the above, the main hypothesis of the research is that household savings in Bosnia and Herzegovina initiate economic growth. For the purpose of comprehensive analysis, the research also includes another component of private savings, savings of private for-profit companies, but given the negligible share in total private savings in Bosnia and Herzegovina, no specific hypothesis is defined for the relationship between private profit savings and economic growth.

In order to test the set hypothesis, Granger's causality test, the Toda-Yamamoto procedure, will be applied.

The paper is divided into five parts. After introductory remarks, a theoretical framework is given with a brief overview of the postulates of basic theories of economic growth. The third part of the paper provides an overview of the empirical literature dealing with the problem of endogenous savings and economic growth. The fourth part of the paper presents the research methodology, more precisely the basic principles of Granger's causality test. The results of the research, the fifth part of the paper, is the most important part, where the results of the research are presented with an appropriate discussion. At the end, concluding remarks were given with summarized results of the conducted research.

\section{Theoretical framework}

When it comes to theories dealing with economic growth, meaning the the relationship between savings and economic growth, two/three significant theories stand out in the literature: Keyenes' hypothesis, neoclassical (Harrod-Domar's and Solow's) theory of growth, and endogenous theory of economic growth.

One of the most significant works in this field was offered by Keyens, in 1936, and that is the "General Theory of Employment, Interest and Money". According to Keyens, only in conditions of full employment can the classical theory be considered valid. However, full employment conditions are the expectation rather than the rule. The real conditions are different, and they are based on a series of causal relations as follows: entrepreneurs earn income by selling goods and services; as income grows, so does consumption, but to a lesser extent than income; differences in the percentages of income and consumption growth are reflected in savings; there is an imbalance between supply and demand, if savings are not put into operation through investment activities; entrepreneurs' expectations regarding future incomes become pessimistic, and therefore they do not create new jobs, but also abolish existing ones; eventually, unemployment gradually rises and demand for goods and services declines.

The theory assumes that the amount of savings and the amount of investment are necessarily equal since both amounts represent the value of income that exceeds consumption. The amount of savings is the result of the collective behavior of individual consumers, and the amount of investment is the result of the collective behavior of individual entrepreneurs. This conclusion, as stated, is not the result of any personality or subtlety of the set definition of income. Namely, the equality of savings and investment necessarily appears in traditional theory, if income is equal to the value of current output, current investment equal to the value of the part of current output that is not consumed, and savings equal to the value of income that exceeds consumption.

The Harrod-Domar model is the first and simplest growth model, which is a long-term projection of Keynes' short-term analysis. Harrod-Domar's theory 
originated in the late 1930s and mid-1940s (Harrod 1939; Harrod 1948; Domar 1946). Capital factors are cited as crucial factors of economic growth in the Harrod-Domar model. Based on the adjustment of supply and demand, the model tries to explain the possibility of stable growth.

According to the model, in order to ensure a state of equilibrium, it is necessary that the expenditures generated by investments be large enough to absorb the growth of output, as a result of investments. Investments not only cause consumption, but also lead to the expansion of the productive capacities of the economy. The theory argues that there must be a balance between the volume of consumption generated by investments and the productive capacities created by investments. The model points out that excessive capital accumulation unaccompanied by adequate income growth causes hyperproduction, unemployment, and economic depression. That is why net investment must grow continuously in order to maintain full employment in the long run. If net investments grow, then real income must grow at a rate that will ensure the use of the full capacity of the increased capital stocks. The required income growth rate is called the "full capacity growth rate" or guaranteed growth rate.

Solow's theory of growth is the result of the work of authors Robert Solow and Trevor Swan from 1956, and is sometimes called the neoclassical model of growth. According to Solow's model, the drivers of economic growth are three factors: technology, capital accumulation and labor. This theory extends Harrod-Domar's model to the following elements: labor factors are included in the factors of production; declining returns on labor and capital are required when variables are viewed separately, and constant returns when variables are viewed in combination; introduction of variable technology, which depends on time and differs from labor and capital.

The Solow model points out that an increase in the accumulation of capital and labor leads to a higher rate of economic growth, but this is of a short-term nature given the declining returns. If the economy had only one worker, adding another would result in a significant increase in output. However, if thousands of workers are employed in the economy, one new worker will not significantly contribute to output growth. In this case, there can be a growth of the economy at a stable rate, where the gross domestic product grows at the same rate as productivity and labor. The rate of economic growth, according to the model, can only be increased by innovations and improvements in technology once a stable rate of growth is achieved with resource utilization.
In addition to the previously mentioned dominant theories of economic growth, it is certainly important to mention the endogenous theory of economic growth. This theory was officially published in his article, "A contribution to the Empirics of Economic Growth", by David Romer, Gregory Mankiw and David Weil in 1992, and is an upgrade of the neoclassical theory of growth.

The theory of endogenous growth is an economic theory that claims that economic growth is generated within a system as a direct result of internal processes. According to this theory, increasing the human capital of a nation will lead to economic growth through the development of new forms of technology and efficient and effective means of production. The theory argues that knowledge-based industries play a particularly important role - especially telecommunications, software, and other high-tech industries -as they become increasingly influential in developed and developing economies.

Some other important postulates of the endogenous theory of economic growth are: government policies can increase a country's growth rate if they lead to stronger competition in markets and help encourage product and process innovation; returns on capital investment, especially in infrastructure and investment in education, health and telecommunications; private sector investment in research and development is a key source of technological progress; the protection of property rights and patents is key to providing incentives for companies and entrepreneurs to engage in research and development; investing in human capital is a vital component of growth; government policy should encourage entrepreneurship as a means to start new businesses and ultimately as an important source of new jobs, investment and further innovation.

\section{Literature review}

Domestic savings can be a significant catalyst for growth, as higher savings rates allow investment to grow at higher rates and further economic growth. The causal link between savings and economic growth has been much discussed in the literature on economic growth and development, however the question of the direction of this link has not yet been unambiguously determined. Proponents of Solow's theory point out that saving alone produces economic growth. Jagadeesh (2015), Nwanne (2016), Kim (2017), Patra et al. (2017) for long-term savings, also confirm that savings initiate economic growth.

On the other hand, using regression and Granger's 
causality test, the authors found that economic growth is a positive function of savings, e.g. Bayar (2014). To model an effective growth policy, it is important to know the direction of the causality of savings and economic growth. Thus, if savings really drive growth then a development policy to encourage savings will be applied. If savings do not cause economic growth, a policy of discouraging savings and strengthening consumption will be applied.

Also, AbuAl-Foul (2010), in econometric analysis of the long-run relationship of savings and growth shows that the link between savings and economic growth exists and is two-way in Morocco, but not in Tunisia (the link in this case was one-way, from growth to savings). Shah (2015), applying the unit root test, cointegration, Granger's causality test and vector error correction model, finds that savings contribute to economic growth in Nepal and India, i.e. growth contributes to savings in Bhutan and Sri Lanka, while causality does not exist at all in Pakistan. Adam, Musah and Ibrahim (2017) conduct an econometric analysis of the causality of savings and economic growth in 10 sub-Saharan African countries. Granger's causality test and Toda-Yamamoto approach give consistent results for only three countries: Benin, Mali, and South Africa, where savings causes economic growth. For other countries, no consistent results were obtained using the same methodology. Wyk and Kapingura (2021) also conduct an analysis of the relationship between savings and economic growth in South Africa and find that the relationship exists only in the short run, while tests do not show a link between the two variables in the long run. The Granger test found that when a relationship is positive it goes in the direction that economic growth causes savings.

An alternative approach to exploring the link between savings and economic growth in Mexico, for the period 1970-2000, was given by Alguacil et al. (2004). Namely, the authors use Toda and Yamamoto's, and Dolado's and Lutkepohl's (non) causality test, stating that Granger's test is more sensitive to the included variables in the model. The analysis shows that savings are causing economic growth in Mexico.

Tang (2008) in his study uses a relatively new cointegration test, the "border test" in the process of investigating the existence of a long-term link between savings and economic growth. The analysis was conducted for Malaysia. The intensity and direction of the link between savings and economic growth was conducted using Toda and Yamamoto, Dolado and Lutkepohl approaches within the augmented-vector autoregressive (VAR) methodology. Using this procedure, the author found that there is a bidirectional link between savings and economic growth. In the continuation of its research, Tang (2009a) conducts an analysis of the sensitivity of the proven causality of savings and economic growth to the tests used. Five different causality tests were used to test sensitivity: Granger's, Geweke's, Meese's and Dent's, Hsiao's, Toda's and Yamamoto's, and Holmes 'and Hutton's causality test. The bidirectional causality of savings and economic growth was determined regardless of the test used. Thus, the method of determining causality, in this case, does not affect the results. Tang (2009b) showed in his further studies that savings and economic growth cause each other to cause each other in the economies of East Asia as well.

Tang and Tan (2014) conducted an empirical analysis of the relationship between savings and economic growth, now in Pakistan, using Solow's neoclassical growth model. It was determined that the variables are cointegrated, and that they are bidirectionally causal.

Guma and Bonga-Bonga (2016) observe for the first time the separate impact of individual savings components on economic growth in South Africa. The authors look separately at the impact of savings: households, private companies and government on economic growth. According to the results of the econometric analysis, the greatest impact on economic growth is achieved by the savings of private for-profit companies.

A certain number of authors have tried to explain the problem of endogenous savings and economic growth by introducing additional variables into the model. Mohan (2006) also includes the size of income among different countries in the analysis and finds that income plays a significant role in the relationship between growth and savings, and that growth affects savings in a number of countries considered. Olajide (2009), emphasizes the importance of foreign direct investment on the ratio of savings and growth, where the growth of savings and investment produces economic growth. Joshi, Pardhan and Bist (2019) analyzing the relationship between savings, investment and economic growth determine that the investment have a positive impact on economic growth, and savings have a negative impact on economic growth in the long run.

It is especially interesting that the analyzes show different results for the same countries, e.g. for the United States. Dhakal et al. (1992). apply Granger's causality finding that, in the United States, there is a two-way link between savings and economic growth, but also that growth exclusively implies savings. Or, Cullison (1993), also applying Granger's test of causality, shows that at the same time, in the US, there is no causality between savings and economic growth, but 
also savings exclusively imply economic growth.

In the countries of Southeast Europe, banks play a central role in the financial markets, so bank deposits appear as the most common form of savings, instead of, for example, investments in the capital market. If the capital market was more developed in these countries, in the sense that the state issues securities for infrastructure, holding bonds of this type would be more profitable than demand deposits because it would bring higher interest yields. Thus, short money, which includes foreign bank assets and central bank reserves above required reserves, would be transformed into investments through the capital market, i.e. short money would actually be a source of savings through the capital market. The condition for the former is market liquidity.

However, the presence of the dominant form of savings in the countries of Southeast Europe (deposit savings) does not give significantly different results in terms of the problem of uniformity of savings and economic growth. Turan and Gjergij (2014) analyzing the relationship between savings and economic growth in Albania found that there is cointegration among the variables involved, but not causality. On the other hand, Ribaj and Mexhauni (2021), analyzing the relationship between savings and economic growth in Kosovo, find that savings in the form of deposits have a significant positive impact on the country's economic growth.

Based on the above, it can be concluded that the direction and intensity of the relationship between savings and economic growth is significantly determined by the applied methodology and by characteristics of the considered economy. This fact provides additional confirmation of the correctness of the observations of individual countries in the analysis of this problem of endogeneity.

\section{Research methodology}

\subsection{Overview of the state of savings in Bosnia and Herzegovina}

Private savings in Bosnia and Herzegovina recorded a continuous growth in the period 2000-2016, according to the Central Bank of Bosnia and Herzegovina. The dominant part of private savings is household savings. The share of household savings in total private savings ranges from $40-90 \%$.

Since savings are the most liquid part of assets, then households try to invest such funds in a way that achieves certain returns. There are opinions that households opt for savings because they do not have enough funds for more demanding and larger financial projects, or to save in order to raise funds for such projects.

In Bosnia and Herzegovina, it is evident that the population does not deposit all funds separated from spending on savings in the form of deposits with commercial banks or similar savings and loan institutions. A large part of the funds, especially the anchor currency (euro) and foreign currency in general, is held outside the financial and banking sector in Bosnia and Herzegovina. Proof of the above is the fact that in 2001, and in the first quarter of 2002, the Central Bank purchased and transposed German marks (DEM) to Germany in the amount of 4.87 billion DEM. During this period, about 20 million DEM was bought daily, and that speaks volumes about the foreign currency stocks that the population kept outside commercial banks.

It can be seen from the bulletin of the Central Bank of Bosnia and Herzegovina (2000-2016) that at the end of September 2016, total household deposits amounted to BAM 10.25 billion. This is also the largest growth in deposits so far. The share of household deposits in total deposits of commercial banks in Bosnia and Herzegovina is $59.6 \%$.

Compared to the end of September of the previous year, 2015, household deposits increased by $6.6 \%$ or BAM 633.5 million. Compared to December 2008, when the economic crisis began, deposits are constantly growing in the range of $8-15 \%$ annually. Thus, a cumulative growth of deposits of $97 \%$ or BAM 5.05 billion was achieved.

The growth rate of deposits changes differently if different maturity structures of deposits are observed. The fastest growth is achieved by short-term deposits, more precisely transaction accounts and demand deposits. Compared to September 2015, transaction accounts increased by 329 million, or $16.3 \%$, while demand deposits increased by BAM 300 million or $13.7 \%$.

The largest percentage of household deposits, in September 2016, were savings and time deposits of $52.8 \%$. Transaction accounts and demand deposits account for $47.2 \%$ of total household deposits.

When it comes to the currency structure of household deposits, in September 2016, the largest share was occupied by deposits in euros $51.1 \%$ or 5.25 billion BAM, then in BAM currency $43.6 \%$ share or 4.47 billion BAM, and deposits in other foreign currencies $5.3 \%$ or BAM 539 million.

Savings and time deposits of private for-profit companies achieved the highest growth from 2005 to the last quarter of 2008 and the beginning of the global financial crisis. The cumulative growth of deposits in 
the observed period amounted to $78.72 \%$. The decline in savings and time deposits of private for-profit companies was recorded by the end of 2010 .

Unlike the savings of private companies, household savings have been growing continuously since the beginning of the global economic crisis, December 2008. In the period from the beginning of the economic crisis to the third quarter of 2016, household savings grew continuously at a rate of $8-15 \%$, which is a cumulative as much as $97 \%$, as noted earlier.

It can be concluded that private corporate deposits were more affected by the global crisis than household deposits, which is to be expected, given that it is a for-profit sector that is much more sensitive to economic fluctuations than the household sector, where precautionary savings occur. in times of crisis.

Savings and time deposits of private for-profit companies recorded a gradual, slight increase from 2010-2016, but with constant oscillations to various changes.

As previously pointed out, the financial market of Bosnia and Herzegovina is dominated by the banking sector, with banks that are subsidiary companies of foreign "mother" banks. These institutions have contributed to increasing market competitiveness and consequently reducing interest rates. This fact becomes questionable if we take into account that the financial market is not sufficiently developed to ensure the competitiveness of various financial institutions. Also, the interest rate is above those in the euro area. The influence of political risk on the interest rate should not be neglected.

The overall situation in the Bosnia and Herzegovina's financial market shows a mismatch between short-term sources and long-term investment needs, as is generally the case in underdeveloped and low-income developing countries. The functioning of the financial market is significantly influenced by the CBR (currency board regime - this system implies a fixed exchange rate of BAM. Each issued BAM has coverage in foreign currency or monetary liabilities must never be higher than the foreign exchange assets of the Central Bank of Bosnia and Herzegovina). The currency BAM is linked to the currency "anchor" euro, so the purchase of BAM is made at a fixed exchange rate of 1.95583 BAM for one euro), which imposes very rigid and strict rules. The mismatch between shortterm sources of funds and long-term investments, accompanied by the underdevelopment of the domestic market for the necessary maturity transformation and the rigidity of the monetary system, is resolved externally by financing through "parent" banks that perform the necessary transformation.

Analyzes show (e.g. Kreso and Begović 2012) that
Bosnia and Herzegovina's commercial banks have more assets than liabilities abroad, net foreign assets is positive, which means that this method of maturity adjustment of funds is extremely expensive and results in a high imbalance of interest rates between foreign assets and obligation. The study also points to the importance of developing the domestic financial market because it would enable more efficient use of available funds and reduce the costs of adjusting funds because it would avoid the impact of political risk on interest rates and increase competitiveness.

The development of financial markets and a deeper financial structure would also mean more effective work of the Central Bank and the overall monetary system, where the effect of expansion would expand from financial markets to the real economy. Greater efficiency of the monetary multiplier effect would improve the effectiveness of available resources in the financial system.

\subsection{Defining model variables}

In this research, two models were developed, as mentioned earlier. One model is related to the relationship between household savings and economic growth, and the other model is related to the relationship between private profit enterprises savings and economic growth. Therefore, the following variables are included: household savings, savings of private for-profit companies and GDP.

Household savings were measured as the sum of household savings and time deposits and this was used as a variable expressed in absolute terms in BAM and in relative terms, as a percentage of GDP.

Savings of private companies represent the sum of savings and time deposits of profitable private companies. In this case, too, savings in absolute amount and as a measure expressed as a percentage of GDP are used.

Data on household savings and profits of forprofit companies were taken from the database of the Central Bank of Bosnia and Herzegovina (bulletins from 2000-2016). According to the methodology of the Central Bank of Bosnia and Herzegovina, a household or a population means one or more persons who earn income on the market through their work, spend the earned income, and if it is a community, share a place of residence. Private for-profit/non-financial enterprises, according to the same methodology, are enterprises in majority private ownership of legal or natural persons engaged in the production and sale of goods and/or services for the purpose of gaining profit. 
Time series of gross domestic product at current and constant prices required additional preparation in order to be used as variables in defined models. Namely, the relevant institutions in Bosnia and Herzegovina do not have quarterly data on gross domestic product for the observed period 2000q1$2016 q 4$, so additional recalculations were needed. The time series of the quarterly gross domestic product at current prices was obtained from the Release of the Agency for Statistics of Bosnia and Herzegovina (2013 and 2016). The estimate of the time series of the quarterly gross domestic product in current prices in the period from $2000 q 1$ to $2005 q 4$ is taken from the paper by Čolaković and Hlivnjak (2007).

The time series of the quarterly gross domestic product at constant prices (prices from 2010) was obtained from Release Agency for Statistics of Bosnia and Herzegovina (2016, this is a time series of chainlinked values in prices in 2010). In the Release of the Agency for Statistics of Bosnia and Herzegovina 2013, the values of the quarterly gross domestic product of chain-linked values in $\mathbf{2 0 0 5}$ prices are given. These values were converted into chain indices which were then used to calculate the value of the quarterly gross domestic product of chain-linked values, but now at 2010 prices. This reconstructed the series of real GDP in the period from $2006 q 1$ to $2016 q 3$ in 2010 prices.

The real GDP series in the period from $2004 q 1$ to $2005 q 4$ was reconstructed taking into account the estimates of the GDP series in current prices from the paper Čolaković and Hlivnjak (2007). The ratio of the real GDP series to the GDP series at current prices in 2006 varied from quarter to quarter, taking values of $1.34,1.21,1.25$, and 1.02 from the first to the fourth quarter, respectively. Precisely these quarterly values were used to multiply the values of the GDP series in current prices in the period 2004q1 to 2005q4, thus obtaining a rough estimate of real GDP in 2010 prices. As the variable GDP growth rate variable was used in the analysis instead of the level of that series, this rough estimate of the value of real GDP satisfies the needs of the analysis in which the dynamics of the series change is observed, and not its level in absolute amount.

\subsection{Research methods}

When using economic indicators in the form of time series, it is necessary to do their seasonal adjustment in order to exclude the influence of the season, i.e., to exclude short-term fluctuations in the phenomenon. The total variance of the time series is significantly determined by the seasonal variation of the series.
Therefore, a large variance, prognostic error, occurs in the case of neglecting the importance of seasonal influence, so it is necessary to conduct the analysis on seasonally adjusted, time-adjusted data. The application of seasonal adjustment methods is aimed only at assessing and eliminating the seasonal impact, without analyzing or explaining the cause of seasonal phenomena.

During this research, $\mathrm{X}-13$ ARIMA and TRAMO/ SEATS methodologies were used for the purpose of seasonal adjustment of time series data. The aim was to check whether both methods give equal results. Both approaches to seasonal adjustment were found to give almost identical results, so it was decided to use only the latest version of the first X-13 ARIMA program in this study.

Two-unit root tests were used to examine the stationarity of the included variables: the Augmented Dickey-Fuller test (ADF) and the Kwiatkowski-PhillipsSchmidt-Shin (KPSS) test. Unlike the ADF test, which takes the nonstationarity of a process as a null hypothesis, the KPSS test claims the stationarity of a process with a null hypothesis (Bahovec and Erjavec 2009). Therefore, the KPSS test is mainly used for the purpose of confirmatory analysis, verification of results obtained using the ADF test or some other single root test.

When assessing whether one time series can serve in predicting another, the Granger test of causality (Granger 1969) is most often used, as can be seen from a review of the empirical literature. Unlike regression, which only indicates a mere relationship between variables, Granger's causality test tests whether the future value of one variable can be predicted based on the past values of another variable. From an econometric point of view, the Granger test is considered to give "predictive causality" (Granger 1988). The basic definition of the test does not include latent confusion effects or current nonlinear causal relations.

In the following, explanations and the basic formulas of the Granger test will be given in accordance with the article published by the author Granger in 1988.

A variable $X$ can be said to cause a variable $Y$ according to the Granger test, if by t-test and F-test lagged values of $X$ it can be proved that the values of $X$ give enough statistically significant values about future values of $Y$. Thus, the variable $X$ causes according to Granger's test, the variable $Y$ if the predictions of the $Y$ series are better based on past data and $X$ and $Y$, than only based on $Y$.

The Granger test is based on two principles. First, the causality of variables arises before their effects. Here the term cause corresponds to the term precede. The assumption is that the past and the present 
cannot be caused by the future. Thus, if event $A_{1}$ is preceded by event $A_{2}$ then $A_{1}$ cannot cause $A_{2}$. Also, if $A_{1}$ occurs before $A_{2}$ it does not necessarily mean that $A_{1}$ causes $A_{2}$. Another assumption is that causality contains unique information about future effects. When determining the causal effects of $X_{t}$ on $Y_{t}$, the following hypothesis is tested taking into account the given assumptions:

$$
P(Y(t+1) \in A \mid I(t)) \neq P\left(Y(t+1) \in A \mid I_{-x}(t)\right) .
$$

In this expression, the notations are used: $P$ for probability, $A$ for an arbitrary non-empty set, and with $I(t)$ and $I_{-X}(t)$ available information at time $t$. It is concluded that $X$ causes $Y$ according to the Granger test if this hypothesis can be confirmed.

The general rule of the Granger test (Granger 1988 ) is that in the case of a time series analysis that is stationary, the absolute values of the variables are used, while for nonstationary series, the corresponding differences for which the variables are stationary are used. Similar to previous tests, Granger's methodology uses Akaike or Schwarz information criteria to select the lags length. The regression equation retains the individual lagged value of a variable if two conditions are met: the value is statistically significant according to the t-test and if the observed value and other lagged values of the variable together increase the exploitative power of the model according to F-statistics. If the lagged values of the explanatory variable are retained in the regression, then the null hypothesis of the absence of Granger causality cannot be rejected.

The results of the Granger test may show that neither variable causes the other, or, if two variables are observed, that the variables cause each other.

The simplest form of the Granger test (Granger 1988 ) is for models that include two variables, $Y_{t}$ and $X_{t}$. The starting point is the assumption that these are stationary series. In order to test the null hypothesis, it is necessary to first determine the appropriate number of $Y_{t}$ lags that will be included in the one-variant autoregression $Y_{t}$ :

$$
Y_{t}=a_{0}+a_{1} Y_{t-1}+a_{2} Y_{t-2}+\ldots+a_{m} Y_{t-m}+\varepsilon_{t} .
$$

In the next step, the autoregressive equation is extended with lags of the variable $X_{t}$ :

$$
Y_{t}=a_{0}+a_{1} Y_{t-1}+a_{2} Y_{t-2}+\ldots+a_{m} Y_{t-m}+\varepsilon_{t} .
$$

where $p$ and $q$ denote the shortest and longest displacements, respectively, for which the lagged values of the variable $X_{t}$ are significant.
The regression equation can retain all individual statistically significant $X_{t}$ lags according to $t$-statistics. The condition for this setting is that in the total amount, all lags, according to F-statistics, contribute to the increase of the regression power.

A multivariate Granger causality test (Granger 1988 ) is used to define vector autoregressive models. Here it is set that $X(t) \in R^{d x i}$ for $t=1, \ldots, T$ is a d-dimensional multivariate series. The VAR model uses the following form of the Granger causality test:

$$
X(t)=\sum^{L} A_{\tau} X(t-\tau)+\varepsilon_{t} .
$$

In the preceding expression, $X_{i}$ is called the Granger causality of some other variable $X_{j}$ provided that at least one element, for, in the absolute value is significantly greater than zero.

Linear testing in the Granger test is suitable for determining causality in the mean values of variables. In this way, Granger's causality for "larger moments" such as variance cannot be determined. Therefore, a nonparametric Granger causality test was developed. The definition of causality in this test is general so that it does not include some modeling assumptions, as is the case with linear autoregressive models. Better parametric models, including those with more momentum and/or nonlinearity, can be set up based on Granger's nonparametric causality test.

Granger's causality test, however, has certain limitations and shortcomings during its application (Maziarz 2015). The first drawback is that Granger's causality does not necessarily mean "true causality." The only thing that Granger's test satisfies in terms of causality is Humaean's definition of causality. Another drawback is that the alternative Granger hypothesis cannot be rejected if both variables, $X_{t}$ and $Y_{t}$, are derived from a common third process with different lags.

Also, it is possible that there are no changes in the other variable if only one variable is manipulated. The Granger test is generally developed for testing pairs of variables, so deficiencies may occur if the "right" relation includes three or more variables. Incorrect test results can also be caused by: a nonlinear causal relationship between variables; non-stationarity and nonlinearity of the observed series; insufficient or excessive sampling; and the existence of rational expectations. By vector autoregression, a similar test can be applied to a number of variables included in the model.

Granger's causality test continued to evolve despite the aforementioned limitations. Thus, a form of the test was developed that is not sensitive to violating the assumption about the normality of the model error distribution. Since most financial variables are 
not normally distributed then the extended version of the Granger test finds special application in analyzes of causality in finance. Asymmetric causality is especially emphasized in recent works in the field of causality, with the aim of separating the impact of positive and negative changes on causality.

\section{Research results}

Two software programs were used in the study including: EViews 9.5 and $R$ with a number of packages created for time series analysis.

In order to verify the existence of causality between household savings and economic growth, as investigated earlier, Granger's causality test was applied, namely the Toda-Yamamoto procedure.

The Toda-Yamamoto procedure first required to determine the order of integration of the two variables between which it was sought to check whether there was a causal relationship in Granger's sense. This was done using ADF and KPSS unit root tests (results of unit root tests, cointegration and VAR models are attached to the paper).

When the results of unit root tests are obtained, it is necessary to determine the maximum order of integration $\mathrm{m}$ of the observed two variables. Thus, it was obtained that household savings are I (1) process while GDP growth rate I (0) is a process. This means that the maximum order of integration is $m=1$.

The next step defines the Vector autoregression (VAR) model based on the level of the variables regardless of the results of the unit root tests. Here, household savings and GDP growth rates enter directly into the VAR model. The maximum lag length for the variables in the vector autoregressive model is then determined. The obtained optimal lag length is denoted by $\mathrm{p}$. It is checked whether the VAR model is correctly specified by determining whether there is autocorrelation of VAR model residuals.

If the variables are of the same order of integration, then it can be checked whether they are cointegrated using Johansen's methodology, in order to further verify the results of Granger's causality test. Namely, if two or more variables are cointegrated, then there must be a Granger causality between them in either one or both directions. However, the opposite does not apply, i.e., if there is a Granger causality among the variables it does not mean that the series must also be cointegrated.

Once the appropriate VAR model has been determined, $m$ lags of each variable are added to each of the equations of the VAR model. Granger causality testing is then performed by applying the Wald test to the hypothesis that the coefficients at the first $p$ lags of the first variable are equal to zero. Then the same is done with the coefficients on the first $p$ lags of the second variable. Rejecting the null hypothesis that these coefficients are equal to zero, is equivalent to rejecting the hypothesis of the absence of causality in Granger's sense between the two observed variables. In other words, the rejection of the hypothesis indicates the existence of Granger causality among the variables.

The results of Granger's test of causality among the variables of savings and economic growth are given in Table 1. Granger's test was applied to both the savings of households and private for-profit companies, as components of private savings.

The results of Granger's test of causality indicated that there is no causal link between household savings and economic growth, thus rejecting hypothesis we tested, which claims that household savings in Bosnia and Herzegovina initiate economic growth.

The same results were obtained by: Cullison (1993) for the USA; Sinha (1996) for India; Saltz (1999) for: Colombia, Jamaica, Peru and the Philippines; Agrawal (2000) for Nepal; Agrawal (2001) for Thailand and Korea; Konya (2005) for a large number of countries, Shah (2015) for Pakistan.

The results only confirm the non-existence of a strict rule on the presence and direction of the link between savings and economic growth, even when applying the same methodology in individual countries.

Savings and economic growth show cointegration, which means that the variables have a common stochastic trend. However, the underdevelopment of the financial and overall economic market, along with the rigidity of the political system, prevents the necessary flow of sufficient capital for faster economic growth, which is an imperative in the Bosnia and Herzegovina's economy. As in the case of other poor economies, the Bosnia and Herzegovina's economy finances its economic growth with expensive foreign capital.

A possible cause of such results is perhaps the more significant effect of demographic and cultural factors on economic growth in Bosnia and Herzegovina. Numerous authors emphasize the importance of including these variables in the research: Prskawetz et al. (2007), Crenshaaw and Robinson (2010), Basu et al. (2013), Diep (2015), Yanagizawa-Drott and Compante (2015), Gorodnichenko and Roland (2016).

The inclusion of demographic variables in the model in this study was not possible due to the shortness of time series data.

Turan and Gjergij (2014) analyzing the relationship between savings and economic growth in Albania, an economy quite similar to that in Bosnia 
Table 1. Granger causality test (Toda-Yamamoto procedure)

\begin{tabular}{|l|l|l|l|}
\hline Null hypothesis & Hi-square & p-value & Granger causality \\
\hline Households & & & \\
\hline Savings do not cause GDP growth rate & 0.872 & 0.351 & Absence of G causality \\
\hline Savings do not cause GDP level & 1.827 & 0.177 & Absence of G causality \\
\hline Savings in \% of GDP do not cause GDP growth rate & 3.487 & 0.175 & Absence of G causality \\
\hline Savings in \% of GDP do not cause the level of GDP & 1.036 & 0.309 & Absence of G causality \\
\hline GDP growth rate does not cause savings & 0.256 & 0.613 & Absence of G causality \\
\hline GDP level does not cause savings & 0.613 & 0.434 & Absence of G causality \\
\hline GDP growth rate does not cause savings in \% of GDP & 0.483 & 0.786 & Absence of G causality \\
\hline GDP level does not cause savings in \% of GDP & 0.002 & 0.964 & Absence of G causality \\
\hline
\end{tabular}

Private for-profit companies

\begin{tabular}{|l|l|l|l|}
\hline Savings do not cause GDP growth rate & 2.760 & 0.097 & Absence of G causality \\
\hline Savings do not cause GDP level & 5.946 & 0.114 & Absence of G causality \\
\hline Savings in \% of GDP do not cause GDP growth rate & 0.849 & 0.357 & Absence of G causality \\
\hline Savings in \% of GDP do not cause GDP level & 4.525 & 0.033 & Granger causality \\
\hline GDP growth rate does not cause savings & 0.850 & 0.357 & Absence of G causality \\
\hline GDP level does not cause savings & 4.152 & 0.246 & Absence of G causality \\
\hline GDP growth rate does not cause savings in \% of GDP & 2.761 & 0.097 & Absence of G causality \\
\hline GDP level does not cause savings in \% of GDP & 0.102 & 0.750 & Absence of G causality \\
\hline
\end{tabular}

Source: Author

and Herzegovina, also found that there is cointegration among the variables involved, and stressed that the government should pay special attention to this important issue for faster economic growth.

In this research the null hypothesis of the absence of causality was rejected only in the case of the variables of the share of private for-profit companies savings in the gross domestic product and the level of the gross domestic product. But strictly speaking, this result does not change the general conclusion made above about the absence of a causal link between savings and economic growth, because economic growth is measured by GDP growth rates, not its level.

If the level of significance of the test is reduced to $10 \%$ then the hypothesis of the absence of Granger causality can also be rejected in two cases when the following variables are observed: private for-profit companies savings and GDP growth rate and GDP growth rate and private for-profit companies savings in $\%$ of GDP. But given the significance level of $10 \%$ this can be considered as a very weak confirmation of the existence of Granger causality among the observed variables.

\section{Conclusion}

The importance of the relationship between savings and economic growth, in addition to basic economic theories, has resulted in numerous empirical papers that have tried to at least determine the direction of this relationship. However, no uniform results have been obtained.

This research also examined the direction and intensity of the relationship between savings and economic growth in the underdeveloped economy of Bosnia and Herzegovina. To verify the existence of causality between household savings and economic growth, the Granger causality test was applied, namely the Toda-Yamamoto procedure. The results of Granger's test of causality indicated that there is no causal link between household savings and the private for-profit companies and economic growth.

According to the results of this research, savings and economic growth in Bosnia and Herzegovina show cointegration, which means that the variables have the same stochastic trend. However, the underdevelopment of the financial and overall economic market, along with the rigidity of the political system, 
prevents the necessary flow of sufficient capital for faster economic growth, which is an imperative in the Bosnia and Herzegovina's economy. As in the case of other poor economies, the Bosnia and Herzegovina's economy finances its economic growth with expensive foreign capital.

A possible cause of such results is perhaps a more significant effect of demographic and cultural factors on economic growth in Bosnia and Herzegovina.

The contribution of the conducted research is reflected in the examination of the direction and maturity intensity of causality between savings and economic growth, in small, open economy of Bosnia and Herzegovina. It was found that there is cointegration among the variables, but not causality.

The contribution is reflected in the fact that by examining the direction and intensity of the causality of savings and economic growth, it contributed to the identification of potential sources of financing economic growth through the optimal distribution of accumulated capital. The results show that in Bosnia and Herzegovina there are enough funds in the form of household savings to finance economic growth, the variables show cointegration, but inadequate and rigid distribution prevents causality among these variables.

The biggest limitation in writing this paper was the availability of data. So, time series of gross domestic product at current and constant prices required additional preparation in order to be used as variables in defined models.

It would be useful to conduct such research after a certain period of time, in order to verify the obtained results with longer observed time spans. Also, as noted earlier, it would be important to include demographic and cultural determinants in the form of mediation or moderation variables in models of the relationship between savings and economic growth, although it is a huge challenge with quartery data. In the continuation of the research, it would be useful to conduct such analyzes for the Western Balkans region and make a comparative analysis.

\section{Literature}

AbuAl-Foul, B. 2010. The causal relation between savings and economic growth: Some evidence from MENA countries. Topic in Middle Eastern and African Economies 12: 1-12.

Adam, I. O., Musah, A., Ibrahim, M. 2017. Putting the cart before the horse? Re-examining the relatonship between domestic savings and economic growth in selected SubSaharan African countries. Journal of African Business, 18 (1): 102-123.

Agrawal, P. 2000. Savings, investment and growth in South Asia. Mumbai: Indira Gandhi Institute of Development Research.

Agrawal, P. 2001. The relation between savings and growth: Cointegration and causality evidence from Asia. Applied Economics, 33(4): 499-513.

Agency for Statistics of Bosnia and Herzegovina. 2016. Announcement, Gross Domestic Product-Quarterly Data, No. 4.

Agency for Statistics of Bosnia and Herzegovina. 2013. Announcement, Gross Domestic Product-Quarterly Data, No. 1.

Alguacil, M., Cuadros, A., Orts, V. 2004. Does saving really matter for growth? Mexico (1970-2000). Journal of International Development. 16(2): 281-290.

Bahovec, V. and Erjavec, N. 2009). Uvod u ekonometrijsku analizu, Element.

Basu, T., Barik, D., Arokiasamy, P. 2013. Demographic Determinants of Economic Growth in BRICS and selected Developed Countries, Presented in XXVII IUSSP International Population Conference (IUSSP-2013). August 2013 at BEXCO. Busan, Republic of Korea.

Bayar, Y. 2014. Financial development and domestic savings in emerging Asian countries, Theoretical and applied economics. 21 (7 - 596): 55-66.

Central Bank of Bosnia and Herzegovina, Quarterly Bulletins: from Bulletin 2 in 2000 to Bulletin 3 in 2016.

Crenshaw, E., Robison, K. 2010. Socio-demographic Determinants of Economic Growth: Age Structure, Preindustrial Heritage and Sociolingustic Integration. Social Forces. 88 (5): 2217-2240.

Čokalović, B., Hlivnjak, S. 2007. Estimate of quarterly GDP for the period 2000-2006. ISSN 1840-2593. Central Bank of Bosnia and Herzegovina. Department of Economic Research, Statistics and Publications.

Cullison,W. E. 1993. Saving measures as economic growth indicators. Contemporary Policy Issues. 11(1): 1-8.

Dhakal, D., Grabowski, R., Shields, M. P. 1992. The role of savings in economic development: The U.S. and Japanese experiences. Japan and the World Economy. 3(4): 331-340.

Diep, V. T. T. 2015. Demographic Factors and Economic Growth: The Bi-directional causality in South East Asia. 
The ninth Vietnam Economists Annual Meeting. Da Nang City. August 2015.

Domar, E. D. 1946. Capital expansion, rate of growth, and employment. Econometrica, Journal of the Econometric Society: 137-147.

Granger, C. W. J. 1969. Investigating Causal Relations by Econometric Models and Cross-Spectral Methods. Econometrica. 37: 424 - 438.

Granger, C. W. 1988. Causality, cointegration, and control. Journal of Economic Dynamics and Control. 12(2-3): 551-559.

Gorodnichenko, Y., Roland, G. 2016. Culture, institutions and the wealth of nations. Review of Economics and Statistic. 99 (3): 402-416.

Guma, N., Bonga-Bonga, L. (2016). The relationship between savings and economic growth at the disaggregated level. Economia Internazionale/ International Economics, Camera di Commercio Industria Artigianato Agricoltura di Genova. 70(1): 1-24.

Harrod, R. F. 1939. An essay in dynamic theory. The Economic Journal. 49(193): 14-33.

Harrod, R. F. 1948. Towards a dynamic economics, London, Macmillan.

Jagadeesh, D. (2015). The impact of savings in economic growth: an empirical study based on Botswana. International Journal. 2: 10 - 21.

Joshi, A., Pardhan, S., Bist, J. P. 2019. Savings, investment and growzh in Nepal: an empirical analysis. Financial Innovation. 5 (1): 1-13.

Keynes, J. M. 1936. The general theory of interest, employment and money. Macmillan.

Kim, N. T. and Nguyen, H. H. 2017. Impacts of domestic savings on economic growth of Vietnam. Asian Journal of Economic Modelling. 5(3): 245-252.

Konya, L. 2005. Saving and growth: Granger causality analysis with bootstrapping on panels of countries. Journal of Economic Research. 10: 231-260.

Kreso, S. and Begović, S. 2012. Maturity (mis) matching in currency board (like) regimes. Interdisciplinary management research. 8: $423-428$.

Mankiw, N.G, Romer D., Weil, D. N. 1992. A Contribution to the Empirics of Economic Growth. The Quarterly Journal of Economics. Oxford University Press. 107(2): 407 - 437.

Maziarz, M. 2015. A review of the Granger-causality fallacy. The journal of philosophical economics: Reflections on economic and social issues 8(2): 86-105.

Mohan, R. 2006. Causal Relationship Between Savings and Economic Growth in Countries with Different Income Levels. Economics Bulletin. 5: 1 - 12.

Nwanne, T. F. I. 2016. Implication of savings and investment on economic growth in Nigeria. International Journal of Small Business and Entrepreneurship Research. 2(4): 74-86.
Olajide S. O. 2009. Does Saving Really Matter for Growth in Developing Countries? The Case of a Small Open Economy. http:// economics.ca /2009/ papers/ 0619.pdf. (accessed November 10, 2016)

Patra, S. K., Murthy, D. S., Kuruva, M. B., Mohanty, A. 2017. Revisiting the causal nexus between savings and economic growth in India: An empirical analysis. Economia. 18 (3): 380-391.

Prskawetz, A., Fent, T., Barthel, W. 2007. The Relationship Between Demographic Change and economic Growth in EU. Institut fur Demographie. Osterreichische Akademie der Wissenschaften, Forschungsbericht. No. 32. https:// www.oeaw.ac.at/fileadmin/subsites/Institute/VID/PDF/ Publications/Forschungsberichte/FB32.pdf. (accessed November 15, 2016).

Ribaj, A., Mexhuani, F. 2021. The impact of savings on economic growth in a developing country (the case of Kosovo). Journal of Innovation and Entrepreneurship. 10 (1): 3-13.

Saltz, I. S. 1999. An examination of the causal relationship between savings and growth in the Third World. Journal of Economics and Finance. 23(1): 90-98.

Shah, R. K., (2015), Saving and Economic Growth in South Asia: Evidence from Time Series Analysis. Economic Journal of Nepal. https://www.econbiz.de/Record/saving-and-economic. (accessed November 10, 2016)

Sinha, D. 1996. Saving and economic growth in India. Economia Internazionale. 49 (4): 637-647.

Solow, R. M. 1956). A contribution to the theory of economic growth. The quarterly journal of economics. 70 (1): 65-94.

Tang, C. F. 2008. An empirical modelling on savings behaviour in Malaysia. Labuan Bulletin of International Business and Finance. 6: 57-76.

Tang, C. F. 2009a. Does causality technique matter to savings-growth nexus in Malaysia?. Malaysian Management Journal. 13(1-2): 1-10.

Tang, C. F. 2009b. The savings-growth nexus for Asian economies: New evidence from the timevarying econometrics methods. Paper presented at the Symposium of USM Fellowship Holders 2009. Universiti Sains Malaysia. Penang. Malaysia. 14-15 November.

Tang, C. F. and Tan, B. W. 2014. A revalidation of the savingsgrowth nexus in Pakistan. Economic Modelling. 36: 370-377.

Turan, G. and Gjergji, O. 2014. What is the Impact of Savings on Growth? The Case of Small Open Economy (Albania). Mediterranean Journal of Social Sciences. 5 (13): 360-368.

Yanagizawa-Drott, D. and Compante, F. 2015. Does religion Affect Economic Growth and Happiness? Evidence from Ramadan. The Quarterly Journal of Economics. 130 (2): 615-658.

Wyk, B. F. and Kapingura, F., M. 2021. Unerstanding the nexus between savings and economic growth: A South African context. Development Southern Africa. 38 (5): 828-844. 


\section{APPENDIX 1: Granger causality test}

\section{Household savings vs. GDP growth rate}

\section{Step 1: Unit root tests}

Null Hypothesis: STEDOM_D11 has a unit root

Exogenous: Constant

Lag Length: 0 (Automatic - based on SIC, maxlag=10)

\begin{tabular}{|c|c|c|c|}
\hline & & t-Statistic & Prob.* \\
\hline \multicolumn{2}{|c|}{ Augmented Dickey-Fuller test statistic } & 0.745 & 0.992 \\
\hline \multirow[t]{3}{*}{ Test critical values: } & $1 \%$ level & -3.544 & \\
\hline & $5 \%$ level & -2.911 & \\
\hline & $10 \%$ level & -2.593 & \\
\hline
\end{tabular}

*MacKinnon (1996) one-sided p-values.

\begin{tabular}{|c|c|c|c|c|}
\hline \multicolumn{5}{|c|}{$\begin{array}{l}\text { Augmented Dickey-Fuller Test Equation } \\
\text { Dependent Variable: D(STEDOM_D11) }\end{array}$} \\
\hline \multicolumn{5}{|l|}{ Method: Least Squares } \\
\hline \multicolumn{5}{|c|}{ Date: 05/11/17 Time: 02:18 } \\
\hline \multicolumn{5}{|c|}{ Sample (adjusted): 2001Q1 2015Q4 } \\
\hline \multicolumn{5}{|c|}{ Included observations: 60 after adjustments } \\
\hline Variable & Coefficient & Std. Error & t-Statistic & Prob. \\
\hline STEDOM_D11(-1) & 0.009 & 0.012 & 0.745 & 0.459 \\
\hline C & 79.751 & 45.196 & 1.765 & 0.083 \\
\hline R-squared & 0.009 & Mean dependent var & & 108.185 \\
\hline Adjusted R-squared & -0.008 & S.D. dependent var & & 186.709 \\
\hline S.E. of regression & 187.417 & Akaike info criterion & & 13.337 \\
\hline Sum squared resid & 2037261. & Schwarz criterion & & 13.407 \\
\hline Log likelihood & -398.120 & Hannan-Quinn criter. & & 13.365 \\
\hline F-statistic & 0.555 & Durbin-Watson stat & & 2.624 \\
\hline Prob(F-statistic) & 0.459 & & & \\
\hline
\end{tabular}


Null Hypothesis: STEDOM_D11 is stationary

Exogenous: Constant

Bandwidth: 6 (Newey-West automatic) using Bartlett kernel

\begin{tabular}{lrr}
\hline \multicolumn{2}{l}{} & \multicolumn{2}{c}{ LM-Stat. } \\
\hline Kwiatkowski-Phillips-Schmidt-Shin test statistic & & 0.960 \\
\hline Asymptotic critical values*: & $1 \%$ level & 0.739 \\
& $5 \%$ level & 0.463 \\
& $10 \%$ level & 0.347
\end{tabular}

*Kwiatkowski-Phillips-Schmidt-Shin (1992, Table 1)

Residual variance (no correction)

HAC corrected variance (Bartlett kernel)

\section{KPSS Test Equation}

Dependent Variable: STEDOM_D11

Method: Least Squares

Date: 05/11/17 Time: 02:20

Sample (adjusted): 2000Q4 2015Q4

Included observations: 61 after adjustments

\begin{tabular}{|c|c|c|c|c|}
\hline Variable & Coefficient & Std. Error & t-Statistic & Prob. \\
\hline C & 3259.592 & 266.827 & 12.216 & 0.000 \\
\hline R-squared & 0.000000 & Mean dependent var & & 3259.592 \\
\hline Adjusted R-squared & 0.000000 & S.D. dependent var & & 2083.985 \\
\hline S.E. of regression & 2083.985 & Akaike info criterion & & 18.138 \\
\hline Sum squared resid & $2.61 \mathrm{E}+08$ & Schwarz criterion & & 18.173 \\
\hline Log likelihood & -552.215 & Hannan-Quinn criter. & & 18.152 \\
\hline Durbin-Watson stat & 0.011 & & & \\
\hline
\end{tabular}

(Other appendices of this step are available from the author on any request.)

Conclusion: Household savings are I (1), GDP growth rate is I (0). 
Step 2: Order the VAR model

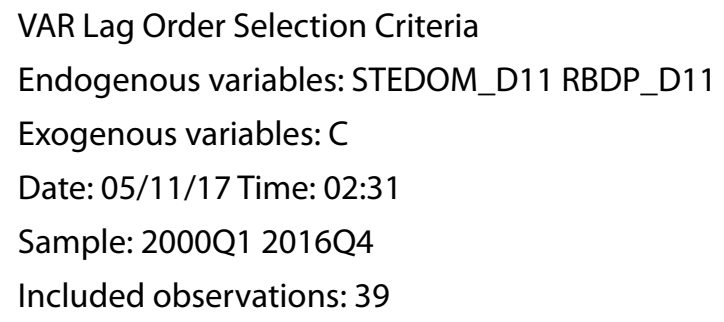

\begin{tabular}{ccccccc}
\hline Lag & LogL & LR & FPE & AIC & SC & HQ \\
\hline 0 & -237.791 & NA & 750.883 & 12.297 & 12.382 & 12.328 \\
1 & -140.014 & $180.511^{*}$ & $6.127^{*}$ & $7.488^{*}$ & $7.744^{*}$ & $7.580^{*}$ \\
2 & -138.860 & 2.012 & 7.106 & 7.634 & 8.060 & 7.787 \\
3 & -137.614 & 2.046 & 8.225 & 7.775 & 8.372 & 7.989 \\
4 & -137.154 & 0.707 & 9.952 & 7.957 & 8.724 & 8.232 \\
5 & -132.120 & 7.229 & 9.576 & 7.904 & 8.842 & 8.240 \\
6 & -131.834 & 0.381 & 11.837 & 8.094 & 9.203 & 8.492 \\
7 & -130.342 & 1.836 & 13.878 & 8.223 & 9.502 & 8.682 \\
8 & -127.907 & 2.747 & 15.677 & 8.303 & 9.753 & 8.823 \\
\hline \hline
\end{tabular}

* indicates lag order selected by the criterion

LR: sequential modified LR test statistic (each test at $5 \%$ level)

FPE: Final prediction error

AIC: Akaike information criterion

SC: Schwarz information criterion

HQ: Hannan-Quinn information criterion

Conclusion: A lag of one quarter 
Step 3: Check the residual VAR (1) of the model

VAR Residual Portmanteau Tests for Autocorrelations

Null Hypothesis: no residual autocorrelations up to lag

Date: 05/11/17 Time: 02:34

Sample: 2000Q1 2016Q4

Included observations: 46

\begin{tabular}{cccccc}
\hline Lags & Q-Stat & Prob. & Adj Q-Stat & Prob. & df \\
\hline 1 & 1.511 & $N^{*}$ & 1.545 & NA* $^{*}$ & NA* $^{*}$ \\
2 & 2.057 & 0.7252 & 2.116 & 0.715 & 4 \\
3 & 3.739 & 0.8799 & 3.915 & 0.864 & 8 \\
4 & 4.815 & 0.9639 & 5.093 & 0.955 & 12 \\
\hline
\end{tabular}

*The test is valid only for lags larger than the VAR lag order.

$\mathrm{df}$ is degrees of freedom for (approximate) chi-square distribution

VAR Residual Serial Correlation LM Tests

Null Hypothesis: no serial correlation at lag order $\mathrm{h}$

Date: 05/11/17 Time: 02:35

Sample: 2000Q1 2016Q4

Included observations: 46

\begin{tabular}{ccc}
\hline Lags & LM-Stat & Prob \\
\hline 1 & 2.086 & 0.720 \\
2 & 0.490 & 0.975 \\
3 & 1.521 & 0.823 \\
4 & 0.977 & 0.913
\end{tabular}

Probs from chi-square with $4 \mathrm{df}$. 


\section{Step 4: Cointegration}

Date: 05/11/17 Time: 02:37

Sample (adjusted): 2004Q4 2015Q4

Included observations: 45 after adjustments

Trend assumption: Linear deterministic trend

Series: STEDOM_D11 RBDP_D11

Lags interval (in first differences): 1 to 1

Unrestricted Cointegration Rank Test (Trace)

\begin{tabular}{ccccc}
\hline \hline $\begin{array}{c}\text { Hypothesized } \\
\text { No. of CE(s) }\end{array}$ & Eigenvalue & Trace & 0.05 & Prob. $^{* *}$ \\
\hline None & Statistic & 21.045 & 15.495 & 0.007 \\
At most 1 & 0.373 & 0.001 & 3.841 & 0.969 \\
\hline \hline
\end{tabular}

Trace test indicates 1 cointegratingeqn(s) at the 0.05 level

* denotes rejection of the hypothesis at the 0.05 level

**MacKinnon-Haug-Michelis (1999) p-values

Unrestricted Cointegration Rank Test (Maximum Eigenvalue)

\begin{tabular}{ccccc}
\hline \hline Hypothesized & Max-Eigen & 0.05 & Prob.** $^{*}$ \\
No. of CE(s) & Eigenvalue & Statistic & 14.265 & 0.004 \\
\hline None $^{*}$ & 0.374 & 21.043 & 3.841 & 0.969 \\
At most 1 & $3.09 \mathrm{E}-05$ & 0.001 & & \\
\hline \hline
\end{tabular}

Max-eigenvalue test indicates 1 cointegratingeqn(s) at the 0.05 level

* denotes rejection of the hypothesis at the 0.05 level

**MacKinnon-Haug-Michelis (1999) p-values

Unrestricted Cointegrating Coefficients (normalized by $\left.\mathrm{b}^{*} \mathrm{~S} 11^{*} \mathrm{~b}=\mathrm{l}\right)$ :

$\begin{array}{cc}\text { STEDOM_D11 } & \text { RBDP_D11 } \\ 0.000 & 66.958 \\ 0.001 & -8.993\end{array}$

\begin{tabular}{ccc} 
Unrestricted Adjustment Coefficients (alpha): & \\
\hline \hline D(STEDOM_D11) & 12.200 & 0.655 \\
D(RBDP_D11) & -0.014 & $1.20 \mathrm{E}-05$ \\
\hline \hline
\end{tabular}

1 Cointegrating Equation(s):

Log likelihood

$-163.913$

Normalized cointegrating coefficients (standard error in parentheses)

$\begin{array}{cc}\text { STEDOM_D11 } & \text { RBDP_D11 } \\ 1.000 & 288124.2 \\ & (56761.5)\end{array}$

Adjustment coefficients (standard error in parentheses)

$\begin{array}{cc} & 0.003 \\ \text { D(STEDOM_D1 1) } & (0.004) \\ \text { D(RBDP_D11) } & -3.35 \mathrm{E}-06 \\ & (6.8 \mathrm{E}-07)\end{array}$

Conclusion: There is cointegration. 
Step 5: Add one lag to VAR (1) and rate VAR (2)

VAR Granger Causality/Block Exogeneity Wald Tests

Date: 05/11/17 Time: 02:43

Sample: 2000Q1 2016Q4

Included observations: 45

Dependent variable: STEDOM_D11

\begin{tabular}{cccc}
\hline \hline Excluded & Chi-sq & df & Prob. \\
\hline RBDP_D11 & 0.256 & 1 & 0.613 \\
\hline All & 0.256 & 1 & 0.613 \\
\hline
\end{tabular}

Dependent variable: RBDP_D11

\begin{tabular}{cccc}
\hline Excluded & Chi-sq & df & Prob. \\
\hline STEDOM_D11 & 0.872 & 1 & 0.351 \\
\hline All & 0.872 & 1 & 0.351 \\
\hline
\end{tabular}

Other appendices of this step are available from the author on any request. 